of trees, too, contains the necessary elements for the support of life; but we do not utilise wood for food, because we have no animals that feed upon wood. Could not chemists do something with wood-pulp in this connection?

The German chemists are reported in the American newspapers to have succeeded in treating sawdust so as to extract a nutritive product that can be digested by man, the so-called "bread from sawdust." ${ }^{\prime}$ If this is true, the British chemists should certainly be able to arrive at a similar result.

How secure Great Britain would be if she, too, could make bread from sawdust, and convert grass and shrubs and other vegetable matter not now utilised into food for her people. Here is a problem of the greatest consequence to Great Britain that should be brought to the attention of her scientific men.

Alexander Graham Bell.

Beinn Bhreagh, near Baddeck, Nova Scotia, July ro.

\section{THE PROMOTION OF RESEARCH BY THE STATE.}

THE Government scheme for the organisation and development of scientific and industrial research, of which we gave particulars last week, represents a welcome concession of a principle always advocated in these columns, and stated with particular force by Sir Norman Lockyer in his presidential address on "The Influence of Brain-power on History," delivered at the Southport meeting of the British Association in 1903. The duty of a State to organise its forces as carefully for peace as for war was emphasised on that occasion; and it was urged that adequate provision for scientific education and research is an essential part of a modern State's machinery, and should be efficiently organised if we were not to fall behind other nations in the applications of science to industry. The recognition of the State's responsibility in this matter would have come much sooner if our statesmen had been wise enough to understand the scientific factors of industrial success; but it has at last been given, and the unanimous approval with which the scheme has been received must be a little surprising to the politicians who have taken so long to realise the part science is playing in the modern world, and to make provision for its national use.

There is nothing, perhaps, so difficult as to alter a long-established tradition, to effect a real change in the mental attitude of a person or of a nation. It is the greatest of revolutions; it is the real revolution on which all action out of harmony with the tradition of the past depends. Such a change of attitude, so far as the official mind of the country is concerned, was announced last May by Mr. Pease, then President of the Board of Education, when he stated in the House of Commons :

The war has brought home to us . . . that we have been far too dependent... upon the foreigner, and we have realised that it is essential, if we are going to maintain our position in the world, to make better

1 For other references to what the German chemists are doing, see article on "Inorganic Fodder" in the Scientific American for July 3, p. 8; in which reference is also made to an attempt to derive from straw and hay all the nourishing matter contained therein.

$$
\text { No. 2388, VOL. 95] }
$$

use of our scientifically trained workers, that we must increase the number of those workers, and that we must endeavour to secure that industry is closely associated with our scientific workers, and promote a proper system of encouragement of research workers, especially in our universities.

These convictions have been translated into deeds through the issue of the Government scheme. The action which has thus been taken by the Government will be hailed by all men of science with feelings of the utmost gratification. It is difficult to overestimate the value of the consequences which may follow-which, indeed, we feel sure will follow-from the adoption of this scheme. By its inception and publication the Government acknowledges and proclaims its appreciation of the work of science, and by this acknowledgment alone it gives scientific workers that encouragement and prestige in the eyes of the country which have too long been withheld.

The expenditure of any new moneys provided by Parliament for scientific and industrial research will be under the control of a committee of the Privy Council, upon the recommendation of the Advisory Council. The appointment of Lord Haldane as a non-official member of the committee of the Privy Council connects the British Science Guild with the work contemplated by the Government scheme. Lord Haldane was the first president of the guild; and at the inaugural meeting in 1905 he said :-

I believe that things will not be right until we have a scientific corps under a permanent committee, just as the Defence Committee is under the Prime Minister to-day. I mean a body that will not consist mainly of officials of the ordinary kind, but of the most eminent men of science, who will be put on the footing upon which they deserve to be placed, and are recognised as a body of men who will be at the elbow of the department and can organise the scientific work of the State. I hope that if we get to this position the example of a Government adopting science will be followed by the municipalities, as I believe it is going to be followed more and more by our manufacturers.

The British Science Guild may justly claim some credit for securing the State assistance for industrial and scientific research now provided for by the Government scheme. For the ten years of its existence it has persistently pointed out that our competitors have brought all the products of science into the contest they have waged against us; and it has urged the adoption of similar methods in our national affairs and manufactures. Scientific men are so closely concerned with their own particular researches that they frequently take little interest in the work of others or in the position which science should occupy in national polity. Their inactivity in this respect is largely responsible for the neglect of science. A public movement was required to direct the attention of the public in general, and the Government and political parties in particular, to the value of the great resources of science in the development of the kingdom; and this movement took shape in the British Science Guild. The purpose of the guild is not so much the acquisi- 
tion of new knowledge as the appreciation of its value, and the necessity of employing scientific methods in all departments of the national executive. We regard the Government scheme as a measure of acknowledgment of the principles of State responsibility and guidance advocated by the guild; and the only regret is that action on these lines was not taken long ago, as it would have been if we had been governed by far-seeing statesmen instead of party politicians. The consequences of Government recognition will certainly be that science will secure increased attention in the thought of the nation generally, and will receive more sympathetic consideration from the industrial world.

The country, as a whole, will be influenced by the lead of the Government. "It appears incontrovertible that if we are to advance or even maintain our industrial position, we must as a nation aim at such a development of scientific and industrial research as will place us in a position to expand and strengthen our industries and to compete successfully with the most highly organised of our rivals." The attitude of mind of the British people, as a nation, towards science, and public estimation and appreciation of its value, must undergo a profound change. It is for the purpose of effecting this change and directing the resulting activity that the Government has established a permanent organisation for the promotion of industrial and scientific research.

The main channels of activity of the organisation, of which the advisory council of seven experts is the most important part, will apparently lie in three directions. First, the advisory council will act as scientific advisers to all Government departments concerned with or interested in scientific research; secondly, the advisory council, with the co-operation of the various scientific societies, will consider the application of science to industry, and will seek to enlist the interest of manufacturers; thirdly, the advisory council will advise the Board of Education as to steps which should be taken for increasing the supply of workers competent to undertake scientific research.

With regard to relations between the manufacturers and the advisory council, it is sincerely to be hoped that the former will lend their utmost assistance to the scheme, which is devised largely in their interests.

On the educational side the work of the advisory council will be of the greatest importance. As has recently been emphasised by Dr. Beilby, "our colleges have two distinct functions to perform, and it is best that this should be clearly recognised, first to allow the future leaders in applied science to come naturally to the top during their training, and secondly, to prepare a large number of well-trained professional men for the organisation and development of industry." How best to secure these two classes of men in adequate numbers, and, more important perhaps, how to induce an adequate number of the right kind of men to enter the chemical profession, will require careful consideration on the part of the advisory council.
It may, however, be hoped that the council will not pin its faith too much to bursaries and scholarships, but will rather seek to create inducements in the shape of posts which are adequately remunerated, more highly remunerated certainly than has been the case in the past.

MODERN PROCESSES OF MANUFACTURING HYDROGEN FOR AIRSHIPS.

$\mathrm{N}$ the Revue Générale des Sciences for June ${ }_{5} 5$, M. A. Fournois reviews the earlier methods for the preparation of hydrogen for balloons, and describes in some detail the more modern processes for its manufacture, especially those adapted to field use. The large amount required in the present campaigns can be conjectured from the capacity of the latest type of Zefpelin, which is stated to be some 30,000 cubic metres.

Many of the earlier processes now possess little beyond theoretical interest. The well-known zincsulphuric acid reaction always presented difficulties in the transport of materials, of which large amounts were required. The dangers attendant to the transport of the acid were largely overcome by absorption with acid sodium sulphate, the solid material being dissolved as required, but some I5 kilos. of the mixture were necessary for the preparation of one cubic metre of the gas.

The electrolytic production was a great advance, although the process was naturally expensive, and only possible at fixed generating stations. When the preparation of chlorine by the electrolysis of salt solutions was developed, hydrogen, being a by-product, was available at a cheaper rate. Such gas must always be supplied compressed in the usual gas cylinders, and here again transport difficulties arose, to say nothing of the dangers inherent to the transport of gas at $\mathrm{r}_{50}$ kilos. pressure into the field. One of the ordinary waggons will carry only some 13 kilos. of hydrogen-a small proportion of the total weight of the load-and this is roughly only onehundredth of the gas required for an ordinary dirigible.

Naturally therefore great attention has been directed during the last few years to methods of preparation suitable for field use. The most successful of these have been the action of water on calcium hydride $\left(\mathrm{CaH}_{2}\right)$ (hydrolite), and the action of caustic soda on ferrosilicon or silicon itself.

Hydrolite is an expensive material-about five francs per kilo.- -but the total cost of the outfit for 50,000 cubic metres is given as only about one-third of the cost of the gas in cylinders, one vehicle sufficing for the transport of the hydrolite plant, as against twelve required for gas cylinders. A vehicle carrying six generators gives an output of 500 cubic metres per hour.

In the ferrosilicon process the fine material falls into caustic soda, which is covered with a layer of hydrocarbon oil to prevent frothing. A base plant has an output of I500 cubic metres per hour; a field plant, comprising two waggons, 400 cubic metres.

NO. 2388, VOL. 95] 